Western University Scholarship@Western

Centre for the Study of International Economic Centre for the Study of International Economic

Relations Working Papers

Relations

1984

\title{
An Investigation in the Theory of Foreign Exchange Controls
}

Jeremy Greenwood

Kent P. Kimbrough

Follow this and additional works at: https://ir.lib.uwo.ca/economicscsier_wp

Part of the Economics Commons

Citation of this paper:

Greenwood, Jeremy, Kent P. Kimbrough. "An Investigation in the Theory of Foreign Exchange Controls." Centre for the Study of International Economic Relations Working Papers, 8431C. London, ON: Department of Economics, University of Western Ontario (1984). 
CENTRE FOR THE STUDY OF INTERNATIONAL ECONOMIC RELATIONS

WORKING PAPER NO. $8431 \mathrm{C}$

AN INVESTIGATION IN THE THEORY OF FOREIGN EXCHANGE CONTROLS

\begin{tabular}{|l|r|} 
Jeremy Greenwood \\
Kent P. Kimbrough \\
SEP 19 Department of Economics Library \\
University of Western Ontario \\
\hline
\end{tabular}

This paper contains preliminary findings from research work still in progress and should not be quoted without prior approval of the author.

DEPARTMENT OF ECONOMICS

UNIVERS ITY OF WESTERN ONTARIO

LONDON, CANADA

N6A 5 C 2 
AN INVESTIGATION IN THE THEORY OF FOREIGN EXCHANGE CONTROLS

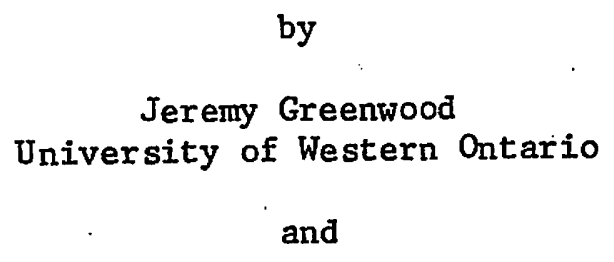

Kent P. Kimbrough

Duke University

August, 1984

Depsrtment of Economics Library

SEP 191984

University of Western Ontario 


\begin{abstract}
A simple choice-theoretic cash-in-advance model is constructed to examine foreign exchange controls. While foreign exchange controls may improve both the exchange rate and the trade balance for a (distortion-free) "small" open economy they reduce its welfare. It is demonstrated that foreign exchange controls act like a quota on imports and raise their relative price in the same manner as a tariff would. Somewhat surprisingly, it happens that shocks to the terms of trade are transmitted negatively to the domestic economy. Finally, it is argued that foreign exchange controls are not the optimal instrument to use to obtain a trade balance objective.
\end{abstract}

Jeremy Greenwood Department of Economics University of Western Ontario Social Science Centre London, Ontario N6A 5C2 Canada
Kent P. Kimbrough Department of Economics Duke University Durham, NC 27706 U.S.A. 


\section{Introduction}

The use of foreign exchange controls is widespread in the world today. It is important, therefore, for the international economist to have a clear understanding about how the adoption of such controls is likely to impact on national economies. This paper examines foreign exchange controls from the perspective of positive economics. The analys is is conducted within the context of a choice-theoretic general equilibrium model which Helpman (1981) proposed as a framework for evaluating alternative exchange rate regimes. This modeling strategy is chosen as it highlights how the adoption of foreign exchange controls limits the opportunity sets facing individuals and alters the incentive structure facing them. Once the effect of foreign exchange controls in agents' decision rules is established it is then easy to infer the ramifications of them for an economy's general equilibrium.

It is shown that foreign exchange controls effectively place a quota on imports and therefore increase their domestic relative price in the same manner as a tariff would. The adoption of foreign exchange controls, in a sense, transforms the imported goods market into a nontraded goods market. Somewhat surprisingly, this can result in shocks to the international terms of trade being transmitted negatively to the domestic economy. While the adoption of foreign exchange controls may improve the trade balance and the exchange rate they tend to worsen welfare for a distortion-free small open economy. Finally, the question of whether foreign exchange controls are the optimal instrument to obtain a trade balance objective is addressed. It is argued they are not. 
II. The Economic Environment

Imagine a small open economy with a flexible exchange rate system that has adopted foreign exchange controls. For simplicity, it will be assumed that this economy has a life span of two periods. It is inhabited by a representative agent whose goal is to maximize his lifetime utility, $\underline{\mathrm{U}}(\cdot)$, as given by:

$$
\underline{U}(\cdot)=\sum_{t=1}^{2} \rho^{t-1}\left[U\left(x^{t}\right)+v\left(z^{t}+\bar{z}^{t}\right)\right]
$$

where $\rho$ is the actor's subjective rate of discount, and $x^{t}$ and $z^{t}+\bar{Z}^{t}$ are his consumption of an exported and imported good in period $t .^{1}$

The representative agent has two sources of income. In each period $t$ the individual is endowed with a certain quantity of the exported good, $\bar{x}^{t}$, and the imported good, $\bar{Z}^{t}$. Also, the agent receives from the domestic government in each period $t$ a nominal transfer payment, $T^{t}$. The exported good can be freely sold in world markets in period $t$ at the world terms of trade, $p^{* t}$, by which is meant the relative price of imports in terms of exports.

Domestic residents can also freely participate on an international bond. market. In the first period the representative agent can purchase or sell real bonds which are denominated in terms of the exported good and pay the fixed internationally determined real rate of return, $r^{*}$. For instance, if during the first period the agent purchased one unit of real bonds, he would receive the equivalent of $1+r^{*}$ units of the exported good during period two.

In the model, the individual must use currency to purchase goods. Furthermore, domestic currency must be used to acquire domestic output while foreign currency is required to buy foreign produced goods. It will be assumed the agent satisfies his demand for the exported and imported good from domestic 
sources first. Thus, if in period the individual purchases $x^{t}$ units of the exported good he will buy them using currency from his current holdings of domestic money, $\mathrm{M}^{\mathrm{t}}$. Likewise, in this period his purchases of imports, $\mathrm{z}^{\mathrm{t}}$, will be bought using currency from his holdings of foreign money, $\mathrm{M}^{* t}$.

A time profile of the individual's life in period $t$ will now be given so as to highlight the circulation of money in the model. The sequencing of monetary transactions outlined here is similar to that adopted by Helpman $(1981) .^{2}$ The representative agent enters period $t$ with a certain amount of domestic and foreign money to spend left over from the previous period, $t-1$. Now at the beginning of period $t$ the individual receives in domestic currency the income from his sales of the imported and exported good during the previous period. This amounts to $P^{t-1} \bar{X}^{t-1}+P I^{t-1} Z^{t-1}$ where $P^{t-1}$ and $P_{I}^{t-1}$ represent the domestic nominal prices of the exported and imported goods during $t-1$. At that time the agent also receives a nominal transfer payment from the government in the amount $T^{t}$.

After receiving this cash the individual then goes to the international bond cum foreign exchange market and redeems the bonds he purchased during the previous period. These bonds are now worth $\left(1+r^{t-1}\right) P^{t} b^{t-1}$ units of domestic money. The individual then purchases new export denominated bonds worth $\mathrm{P}^{\mathrm{t}} \mathrm{b}$ in domestic currency terms. His resulting new holdings of cash are then allocated between holding domestic and foreign currency in the magnitudes $M^{t}$ and $M^{* t}$. On the foreign exchange market a unit of foreign currency can be bought or sold for $e^{t}$ units of domestic money so that $e^{t}$ is the period-t foreign exchange rate. Since foreign exchange controls are in effect the maximum amount of foreign currency the agent can acquire is $\tilde{\mathrm{M}}^{* \mathrm{t}}$.

During the remainder of the period, the individual uses his holdings of domestic and foreign currency to purchase his consumption quantities of the 
exported good, $x^{t}$, and the imported good, $z^{t}+\bar{z}^{t}$. He then will enter period $t+1$ with $M^{t}-P^{t} X^{t}-P_{I}^{t} Z^{-t}$ units of domestic currency and $M^{* t}-P_{I}^{* t} Z^{t}$ units of foreign currency where $P_{I}^{* t}$ is the foreign nominal price of the imported good, and the whole process begins again.

Note that the representative agent is free to sell whatever quantities of the export good he chooses either domestically or internationally as long as the sales are effected using domestic currency. Now assuming that foreign residents can acquire as much domestic currency as they desire at the going foreign exchange rate, $e^{t}$, the law of one price must hold for the exported

$$
\mathrm{P}^{\mathrm{t}}=\mathrm{e}^{\mathrm{t}} \mathrm{P}^{* \mathrm{t}} \quad \forall t=1,2,
$$

good , where $\mathrm{P}^{* \mathrm{t}}$ is defined as the foreign currency price of the exported good. Due to presence of foreign exchange controls domestic residents are not, in general, free to buy as much of the imported good as they choose. As a result of this restriction on trade, the law of one price does not have to hold for imports. This fact will be returned to later on.

Finally, as mentioned, there is a government in this economy. Its sole purpose is to issue (or retire) money via transfer payments to the representative agent and to control the amount of foreign exchange held by him. From the representative agent's perspective these transfer payments are unrelated to his holdings of domestic cash balances.

III. The Agent's Optimization Problem

The agent's goal in life is to attain the highest possible level of welfare in the above environment. The mathematical transliteration of this goal is to solve the following maximization problem where the choice variables are $x^{1}, x^{2}$, $\mathrm{z}^{1}, \mathrm{z}^{2}, \mathrm{~m}^{1} \equiv \mathrm{M}^{1} / \mathrm{P}^{1}, \mathrm{~m}^{2} \equiv \mathrm{M}^{2} / \mathrm{P}^{2}, \mathrm{~m}^{* 1} \equiv \mathrm{M}^{* 1} / \mathrm{P}^{* 1}, \mathrm{~m}^{* 2} \equiv \mathrm{M}^{* 2} / \mathrm{P}^{* 2}$, and $\mathrm{b}^{1}$ : 


$$
\operatorname{Max} U\left(x^{1}\right)+v\left(z^{1}+z^{-1}\right)+o\left[U\left(x^{2}\right)+v\left(z^{2}+\bar{z}^{-2}\right)\right]
$$

s.t.

$$
\begin{aligned}
& \mathrm{m}^{1}+\mathrm{m}^{* 1}+\mathrm{b}^{1}=\mathrm{T}^{1} / \mathrm{P}^{1} \\
& \mathrm{~m}^{2}+\mathrm{m}^{* 2}=\left(\mathrm{P}^{1} / \mathrm{P}^{2}\right)\left[\mathrm{x}^{-1}+\left(\mathrm{P}_{\mathrm{I}}^{1} / \mathrm{P}^{1}\right) \mathrm{Z}^{-1}\right]+\mathrm{T}^{2} / \mathrm{P}^{2}+\left(\mathrm{P}^{1} / \mathrm{P}^{2}\right)\left[\mathrm{m}^{1}-\mathrm{X}^{1}-\left(\mathrm{P}_{\mathrm{I}}^{1} / \mathrm{P}^{1}\right) \mathrm{Z}^{-1}\right] \\
& +\left(\mathrm{P}^{* 1} / \mathrm{P}^{* 2}\right)\left[\mathrm{m}^{* 1}-\mathrm{p}^{* 1} \mathrm{z}^{1}\right]+\left(1+\mathrm{r}^{*}\right) \mathrm{b}^{1} \\
& \mathrm{x}^{1}+\left(\mathrm{P}_{\mathrm{I}}^{1} / \mathrm{P}^{1}\right) \overline{\mathrm{z}}^{-1} \leq \mathrm{m}^{1}, \mathrm{P}^{* 1} \mathrm{z}^{1} \leq \mathrm{m}^{* 1} \\
& \mathrm{x}^{2}+\left(\mathrm{P}_{\mathrm{I}}^{2} / \mathrm{P}^{2}\right) \overline{\mathrm{Z}}^{2} \leq \mathrm{m}^{2}, \mathrm{p}^{* 2} \mathrm{Z}^{2} \leq \mathrm{m}^{* 2} \\
& \mathrm{~m}^{* 1} \leq \tilde{\mathrm{m}}^{* 1}
\end{aligned}
$$

and

$$
\mathfrak{m}^{* 2} \leq \tilde{\mathfrak{m}}^{* 2}
$$

where $\tilde{\mathrm{m}}^{* t}=\tilde{\mathrm{M}}^{* \mathrm{t}} / \mathrm{P}^{* \mathrm{t}}$ (reca11 that $\left.\mathrm{p}^{* t}=\mathrm{P}_{I}^{* \mathrm{t}} / \mathrm{P}^{* \mathrm{t}}\right)$.

The first two constraints, (3.1) and (3.2), are the individual's first and second period budget constraints. The next two set of equations, (3.3) and (3.4), are agent's cash-in-advance constraints in each period and reflect the fact that the individual must use domestic currency to purchase the home produced good and foreign currency to purchase the imported one. Conditions (3.5) and (3.6) represent the constraints imposed by foreign exchange controls on the agent's holding of foreign cash balances.

In the framework used here money is required by the exchange mechanism in order to effect consumption purchases. Agents can choose whether to hold money as a store of value, however, independently of their consumption decisions. This portfolio decision will be made so as to maximize wealth, and hence the asset (or assets) with the highest real return will serve as a store of value. To see the issues involved here, define $\pi^{t}$ as the domestic rate of inflation in period $t$ and $\pi^{k_{t}}$ as the foreign rate of inflation in this period so that $\pi^{t}=\left(P^{t+1}-P^{t}\right) / P^{t}$ 
and $\pi^{* t}=\left(\mathrm{P}^{* t+1}-\mathrm{P}^{* t}\right) / \mathrm{P}^{* t}{ }^{3}$ As long as $\pi^{t}$ and $\pi^{* t}$ are both greater than $-r^{* t} /\left(1+r^{* t}\right)$ the period $t$ cash-in-advance constraints will hold as strict equalities. $^{4}$ That is, so long as the domestic and foreign economies are inflating faster than the optimum quantity of money prescribes, bonds will dominate money as an abode of purchasing power. This condition is assumed to hold in the remainder of the analysis and hence (3.3) and (3.4) are treated as equalities.

By undertaking the maximization routine involved, the following set of first-order conditions can be obtained:

$$
\begin{aligned}
\mathrm{v}_{1}\left(z^{1}+\bar{z}^{-1}\right) & =\left(1+\left(\lambda^{1} / \alpha^{1}\right)\right) \dot{p}^{* 1} \mathrm{u}_{1}\left(\mathrm{x}^{1}\right) \\
\mathrm{v}_{1}\left(\mathrm{z}^{2}+\bar{z}^{-2}\right) & =\left(1+\left(\lambda^{2} / \alpha^{2}\right)\right) \mathrm{p}^{* 2} \mathrm{U}_{1}\left(\mathrm{x}^{2}\right) \\
\mathrm{U}_{1}\left(\mathrm{x}^{1}\right) & =\left(1+\mathrm{r}^{*}\right) \rho \mathrm{U}_{1}\left(\mathrm{x}^{2}\right)
\end{aligned}
$$

where $\alpha^{1}, \alpha^{2}, \lambda^{1}$ and $\lambda^{2}$ are the Lagrange multipliers associated with the constraints (3.1), (3.2), (3.5), and (3.6) respectively. To begin with, equation (3.7) describes how the agent should optimally divide his first-period expenditure on consumption between imported and exported goods. Note that the presence of exchange controls in the first period drives a wedge in the amount $\left(1+\left(\lambda^{1} / \alpha^{1}\right)\right)$ separating the first-period marginal rate of substitution between import and export consumption, $v_{1}\left(z^{1}+z^{-1}\right) / U_{1}\left(x^{1}\right)$, from its equality with the terms of trade, $\mathrm{p}^{* 1}$. Now as long as the foreign exchange controls in the first period are effective the multiplier $\lambda^{1}$ associated with the exchange restriction (3.5) will be greater than zero. ${ }^{5}$ since $\lambda^{1}$ represents the utility value of an extra real unit of foreign exchange, while $\alpha^{1}$ shows the value in utility terms of an incremental unit of first-period real income, the ratio $\lambda^{1} / \alpha^{1}$ illustrates the value of an additional. real unit of foreign exchange.measured in terms of real income--and consequently, like a proportional tariff, is a pure number. 
Thus, with foreign exchange controls in place the effective cost of an extra unit of imports, in the first period can be thought of as being made up of two components. The first component is the $p^{* 1}$ units of exports (or bonds) one must sell on world markets in order to purchase the import good. The second component derives from the value of the foreign exchange needed to purchase the import good. One needs $\mathrm{p}^{* 1}$ real units of foreign exchange in order to buy an extra unit of imports and each extra unit of foreign exchange has a value of $\lambda^{1} / \alpha^{1}$. Hence the domestic total cost of increasing imports by a unit is $\left(1+\left(\lambda^{1} / \alpha^{1}\right)\right) \mathrm{p}^{* 1}$. As can be seen, therefore, when foreign exchange controls are in effect the domestic relative price of imports, $\mathrm{P}_{\mathrm{I}}^{1} / \mathrm{P}^{1}=\left(1+\left(\lambda^{1} / \alpha^{1}\right)\right) \mathrm{p}^{* 1}$, will be above the world leve1, $\mathrm{p}^{* 1}$. Foreign exchange controls raise the domestic relative price of imports above the world level in much the same way as tariff would.

Equation (3.8) shows that a similar condition governs the optimal division of second-period expenditure between imports and exports. Finally, (3.9) is the familiar intertemporal efficiency condition characterizing the agent's consumptionsavings decision.

In passing it will be mentioned that foreign exchange controls are equivalent to certain types of multiple exchange rate systems. To see this imagine that purchases of imports in period $t$ must be effected at a different exchange rate, $s^{t}$. Under this system the representative agent would set the period-t marginal rate of substitution between import and export goods equal to $\left[1+\left(s^{t}-e^{t}\right) / e^{t}\right] p^{* t}$. The term $\left(s^{t}-e^{t}\right) / e^{t}$ represents the effective tariff on imports that the multiple exchange rate system imposes and is similar in nature to the implicit tariff, $\lambda^{t} / \alpha^{t}$, levied by exchange controls. This type of multiple exchange rate system is identical to exchange controls in the same sense that Bhagwati (1965) has argued that tariffs and quotas are equivalent. 
The agent's optimization problem implies that his compensated demand functions for the imported and exported goods will have the following forms:

$$
\begin{aligned}
& \mathrm{z}^{1}=\mathrm{z}^{1}\left(\mathrm{p}^{* 1}\left(1+\eta^{1}\right), \mathrm{p}^{* 2}\left(1+\eta^{2}\right) /\left(1+\mathrm{r}^{*}\right), 1 /\left(1+\mathrm{r}^{*}\right), \underline{\mathrm{U}}\right) \\
& (-) \quad(+) \quad(+) \quad(+) \\
& \mathrm{z}^{2}=\mathrm{z}^{2}\left(\mathrm{p}^{* 1}\left(1+\eta^{1}\right), \mathrm{p}^{* 2}\left(1+\eta^{2}\right) /\left(1+\mathrm{r}^{*}\right), 1 /\left(1+\mathrm{r}^{*}\right), \underline{\mathrm{U}}\right) \\
& \text { (+) (-) } \\
& \text { (t) (t) } \\
& \mathrm{x}^{1}=\mathrm{x}^{1}\left(\mathrm{p}^{* 1}\left(1+\eta^{1}\right), \mathrm{p}^{* 2}\left(1+\eta^{2}\right) /\left(1+\mathrm{r}^{*}\right), 1 /\left(1+\mathrm{r}^{*}\right), \underline{\mathrm{U}}\right) \\
& \mathrm{x}^{2}=\mathrm{x}^{2}\left(\mathrm{p}^{* 1}\left(1+\eta^{1}\right), \mathrm{p}^{* 2}\left(1+\eta^{2}\right) /\left(1+\mathrm{r}^{*}\right), 1 /\left(1+\mathrm{r}^{*}\right), \underline{\mathrm{U}}\right)
\end{aligned}
$$

where $\eta^{t} \equiv \lambda^{t} / \alpha^{t}$ is the implicit tariff imposed on period-t imports by exchange controls. The sign under an argument in one of the demand functions shows the sign of the partial derivative of that demand function with respect to the argument in question. It is needless to say that the agent's level of welfare, $\underline{U}$, is dependent on such things as his endowment of the export and import goods, the terms of trade, the world real interest and the extent of exchange controls. The nature of this dependence is discussed in fuller detail later on

\section{The Impact of Exchange Controls}

Suppose that the government decides to temporarily institute a system of exchange controls in the first period. Exchange controls can be used to achieve a variety of objectives but one of the most common is to restrict the volume of imports to some target level. Assume, therefore, that the government desires to limit the physical volume of imports in period one to $z^{1}$ units. This can be achieved by setting the ceiling on the value of period-one foreign exchange holdings, $\tilde{\mathrm{m}}^{* 1}$, so that $\tilde{\mathrm{m}}^{* 1}=\mathrm{p}^{* 1} \tilde{\mathrm{z}}^{1}$. Note that the imported goods market must clear domestically in the first period in the sense that the demand for imports, $\mathrm{z}^{1}$, must equal the governmentally determined supply for them, $\tilde{z}^{1}$. That is, the following import market clearing condition must hold

$$
\mathrm{z}^{1}=\mathrm{z}^{1}\left(\mathrm{p}^{* 1}\left(1+\eta^{1}\right), \mathrm{p}^{* 2} /\left(1+\mathrm{r}^{*}\right), 1 /\left(1+\mathrm{r}^{*}\right), \underline{\mathrm{U}}\right)=\tilde{\mathrm{z}}^{1}=\tilde{\mathrm{m}}^{* 1} / \mathrm{p}^{* 1}
$$


In response to various shocks to the economy the domestic relative prices for first period imports, $p^{* 1}\left(1+\eta^{1}\right)$, must adjust in order to maintain equilibrium in the imported goods market. The imported goods market in an economy with exchange controls behaves in many respects in the same manner as the nontraded goods market would in an economy with nontraded goods. ${ }^{6}$ (For analysis of nontraded goods see Jones (1974), or more recently Kimbrough (1983) and Greenwood (1983)).

In the model international trade must balance intertemporally. This fact is easily discerned by first discounting equation (3.2) by $\left(1+r^{*}\right)$ and then subsequently adding it to (3.1). Next, on the lefthand side of the resulting equation eliminate the money terms by using the fact that the cashin-advance constraints given by (3.3) and (3.4) hold as strict equalities. Final1y, the transfer payment terms on the righthand side of the new equation can be removed by noting that equilibrium in the money and goods markets implies $\sum T^{j} / P^{t}=\bar{X}^{t}+\left(1+\eta^{t}\right) p^{* t} \bar{z}^{t}$ for all $t .^{7}$ One then obtains $j=1$

$$
p^{* 1} z^{1}+x^{1}+\frac{p^{* 2} z^{2}+x^{2}}{\left(1+r^{*}\right)}=x^{-1}+\frac{\bar{x}^{2}}{\left(1+r^{*}\right)}
$$

Note that with exchange controls in place in the first period $\tilde{\mathrm{Z}}^{1}$ will replace $\mathrm{Z}^{1}$ in the above expression (c.f. $(4.1)$ ).

To aid in understanding how exchange controls effect the economy consider the impact of relaxing first-period exchange controls. The agent can purchase more imports when the government increases the amount of foreign exchange he can hold. Specifically, $d Z^{1} / d^{*} \tilde{m}^{* 1}=1 / p^{* 1}$. In light of this, the impact on the agent's welfare leve1, $\underline{U}$, from a marginal relaxation of the ceiling on the amount of foreign exchange he can hold can be deduced from (2.1), (3.7), $(3.9),(4.1)$ and $(4.2)$ to be

$$
\mathrm{d} \underline{\mathrm{U}} / \mathrm{dm}^{* 1}=\eta^{1} \mathrm{u}_{1}\left(\mathrm{x}^{1}\right)
$$


This expression is easy to interpret. A unit relaxation in first-period exchange controls would allow the agent to purchase an additional $1 / \mathrm{p}^{* 1}$ units of first-period imports. The cost of these additional imports to the economy would be a unit of foregone export consumption. But, as is evident from (3.7), $1 / p^{* 1}$ units of extra import consumption is worth $\left(1+\eta^{1}\right)$ units of export consumption to the agent. Thus, by relaxing the exchange restrictions by a unit the individual realizes a net welfare gain worth the equivalent of $\eta^{1}$ units of first-period exports. This gain, $\eta^{1}$, is converted into utility by multiplying it by the marginal utility of first-period exports, $v_{1}\left(x^{1}\right)$.

It is easy to deduce how this liberalization in first-period exchange controls affects the price for first-period imports, $\mathrm{p}^{* 1}\left(1+\eta^{1}\right)$. This is done by displacing the first-period import clearing condition, (4.1), while making use of (4.3) to get

$$
\frac{d\left[p^{* 1}\left(1+\eta^{1}\right)\right]}{d^{* 1}}=\frac{1-\left(\eta^{1} /\left(1+\eta^{1}\right)\right) \mu_{z}^{1}}{p^{* 1} z_{1}^{1}}<0
$$

(with $\mathrm{z}_{1}^{1} \equiv \partial \mathrm{z}^{1} / \partial \mathrm{p}^{* 1}\left(1+\eta^{1}\right)<0, \mu_{\mathrm{z}}^{1} \equiv\left(1+\eta^{1}\right) \mathrm{p}^{* 1} \mathrm{z}_{4}^{1} \mathrm{U}_{1}\left(\mathrm{x}^{1}\right)$, and $\mathrm{z}_{4}^{1} \equiv \partial \mathrm{z}^{1} / \partial \underline{\mathrm{u}}$ both $>0$ )

where $\mu_{\mathrm{Z}}^{1}$ represents the marginal propensity to consume first-period imports and is less than unity in value. As was probably expected, when exchange controls are loosened the domestic price of imports drops in response to their increased availability.

Note that the decrease in the price for current imports, $p^{* 1}\left(1+\eta^{1}\right)$, is inversely related to the size of the marginal propensity to consume current imports, $\mu_{\mathrm{Z}}^{1}$. The larger this datum the more willing the agent is to increase his demand for imports in response to the improvement in his welfare. Consequently, the less the domestic price of imports will have to fall in response to the increase in current import supply. Also, note that this gain in welfare is directly proportional to the size of $\eta^{1} /\left(1+\eta^{1}\right)$ so that the bigger this magnitude 
is the smaller will be the drop in price. Finally, the fall in current import prices is negatively related to the size of $z_{1}^{1}$ which represents the substitution effect of a change in $p^{* 1}\left(1+\eta^{1}\right)$ on current import consumption. The bigger this substitution effect is, or the more willing the agent is to substitute toward current import consumption and away from the consumption of the other goods as $\mathrm{p}^{* 1}\left(1+m^{1}\right)$ falls, the smaller will be the decline in $\mathrm{p}^{* 1}\left(1+\eta^{1}\right)$.

The first-period trade balance will deteriorate in response to exchange control liberalization. The current trade balance, $t b^{1}$, is defined by $(4.5)$ shown below

$$
t b^{1}=x^{-1}-\left[x^{1}+p^{* 1} z^{1}\right]
$$

Thus, the response of the trade balance to a loosening of exchange controls is

$$
\begin{aligned}
& \frac{\mathrm{dtb}}{d \tilde{\mathrm{m}}^{* 1}}=-1-\eta^{1} \mu_{\mathrm{x}}^{1}-\mathrm{x}_{1}^{1} \frac{\mathrm{d}\left[\mathrm{p}^{* 1}\left(1+\eta^{1}\right)\right]}{\mathrm{d \tilde {m } ^ { * 1 }}}<0 \\
& \left(\text { with } \mathrm{x}_{1}^{1} \equiv \partial \mathrm{x}^{1} / \partial \mathrm{p}^{* 1}\left(1+\eta^{1}\right)>0, \mu^{1} \equiv \mathrm{x}_{4}^{1} \mathrm{U}\left(\mathrm{x}^{1}\right)>0, \text { and } \mathrm{x}_{4}^{1} \equiv \partial \mathrm{x}^{1} / \partial \underline{\mathrm{U}}>0\right)
\end{aligned}
$$

where $\mu_{X}^{1}$ is the marginal propensity to consume first-period exportables. 8 The sign of the above expression is unambiguously negative, a fact which is demonstrated in the Appendix. The first term illustrates the worsening in the trade balance generated by the increased volume of imports now permitted with the new higher quota for foreign exchange. Recall that exchange control liberalization has a positive effect on welfare. This will stimulate the domestic demand for the export good which, as the second term shows, causes a deterioration in the trade balance. The last term indicates the positive impact on the trade balance that a fall in the effective price of current imports has. As the domestic price for imports drops, home demand for exports falls and this has a beneficial effect on the current trade balance.

The current exchange rate depreclates in value when first-period exchange controls are relaxed. Recall that equilibrium in the money and goods markets implies that $\sum_{j=1}^{t} T^{j}=P^{t}\left[\bar{x}^{t}+\left(1+\eta^{t}\right) p^{* t} \bar{z}^{-t}\right]$ for all $t$. Consequently by using the 
law of one price (2.2) the current exchange rate $e^{1}$ can be written as $e^{1}=T^{1} /\left[P^{* 1}\left(\bar{X}^{-1}+\left(1+\eta^{1}\right) P^{* 1} \bar{Z}^{-1}\right)\right]$. Thus, since a liberalization in first-period exchange controls causes the domestic relative price of imports, $\left(1+\eta^{1}\right) p^{* 1}$, to fall, $e^{1}$ must rise implying that the current exchange rate depreciates in value. This drop in the exchange rate occurs because the real value of domestic income, $\bar{x}+\left(1+\eta^{1}\right) p^{* 1} \bar{z}^{1}$, falls leading to a reduction in the demand for domestic real balances. 9 It should be noted that while a relaxation (tightening) in exchange controls causes a deterioration (improvement) in the trade balance and a depreciation (appreciation) in the exchange rate it has a beneficial (deleterious) impact on economic welfare.

The above line of reasoning can also be employed to show that the anticipation of future foreign exchange controls--in an economy which does not currently have foreign exchange restrictions--will worsen the current trade balance and cause a drop in welfare. The movement toward a current trade balance deficit is caused by the fact that in anticipation of future exchange controls individuals will substitute tọard current import (and export) consumption . as the domestic price of future imports rises.

Alternatively, suppose that the exchange controls are permanently in place. Now consider the impact on the economy of an anticipated deterioration in the future terms of trade (i.e. let $\mathrm{p}^{* 2}$ rise while holding $\mathrm{p}^{* 1}$ fixed). In a case where exchange controls are permanently instituted, the imported goods market must clear domestically in each period so that

$$
\begin{aligned}
& \mathrm{z}^{1}=\mathrm{z}^{1}\left(\mathrm{p}^{* 1}\left(1+\eta^{1}\right), \mathrm{p}^{* 2}\left(1+\eta^{2}\right) /\left(1+\mathrm{r}^{*}\right), 1 /\left(1+\mathrm{r}^{*}\right), \underline{\mathrm{U}}\right)=\tilde{\mathrm{z}}^{1} \\
& \mathrm{z}^{2}=\mathrm{z}^{2}\left(\mathrm{p}^{* 1}\left(1+\eta^{1}\right), \mathrm{p}^{* 2}\left(1+\eta^{2}\right) /\left(1+\mathrm{r}^{*}\right), 1 /\left(1+\mathrm{r}^{*}\right), \underline{\mathrm{U}}\right)=\tilde{\mathrm{z}}^{2}
\end{aligned}
$$

where $\widetilde{\mathrm{Z}}^{2}$ is the government's target level of imports for the second period. Also, once again trade must balance intertemporally so that (4.2) holds with a slight modification to incorporate the fact there are exchange controls present in both periods. This modified equation is 


$$
p^{* 1} \tilde{z}^{1}+x^{1}+\frac{p^{* 2} \tilde{z}^{2}+x^{2}}{\left(1+r^{*}\right)}=\bar{x}^{1}+\frac{\bar{x}^{2}}{\left(1+r^{*}\right)}
$$

An anticipated deterioration in the future terms of trade leads

to a decline in the agent's welfare, $\underline{\mathrm{U}}(\cdot)$. The size in this drop in welfare can be shown using $(2.1),(3.7),(3.9),(4.7)$ and $(4.8)$ to be

$$
\mathrm{dU} / \mathrm{dp}^{* 2}=-\mathrm{U}_{1}\left(\mathrm{x}^{1}\right) \tilde{\mathrm{z}}^{2} /\left(1+\mathrm{r}^{*}\right)
$$

As can be seen this fall in welfare is directly proportional to the volume of second-period imports, $\tilde{\mathrm{z}}^{2}$. Next the impact of this temporary deterioration in the terms of trade on the first and second period domestic prices for imports can be determined by undertaking the appropriate comparative static exercise on the system of equations (4.7). One obtains

$$
\begin{aligned}
& \frac{\mathrm{d}\left[\mathrm{p}^{* 1}\left(1+\eta^{1}\right)\right]}{\mathrm{dp}}=\frac{\left[\mathrm{z}_{4}^{1} \mathrm{z}_{2}^{2}-\mathrm{z}_{4}^{2} \mathrm{z}_{2}^{1}\right] \mathrm{u}_{1}\left(\mathrm{x}^{1}\right) \tilde{\mathrm{z}}^{2} /\left(1+\mathrm{r}^{*}\right)}{\Delta}<0 \\
& \frac{\mathrm{d}\left[\mathrm{p}^{* 2}\left(1+\eta^{2}\right) /\left(1+\mathrm{r}^{*}\right)\right]}{\mathrm{dp}}=\frac{\left[\mathrm{z}_{1}^{1} \mathrm{z}_{4}^{2}-\mathrm{z}_{1}^{2} \mathrm{z}_{4}^{1}\right] \mathrm{U}_{1}\left(\mathrm{x}^{1}\right) \tilde{\mathrm{z}}^{2} /\left(1+\mathrm{r}^{*}\right)}{\Delta}<0
\end{aligned}
$$

with $\Delta=z_{1}^{1} z_{2}^{2}-z_{2}^{1} z_{1}^{2}>0.10$

The signs of the above expressions are both unambiguously negative. This follows since the numerators of both expressions are negative while their common denominator, $\Delta$, is positive; this latter fact arises from the negative semidefiniteness of the substitution matrix obtained from the consumer's problem. Thus, an anticipated deterioration in the future terms of trade causes the domestic price of imports in both periods to fall. It may seem a bit surprising that shocks to world relative prices are negatively transmitted to the domestic economy. The intuition underlying this result is straightforward. When the future terms of trade deteriorate the individual feels poorer as (4.9) illustrates. At the original set of relative prices the agent cuts back on his consumption of imports and exports in both periods. With the supply of imported goods fixed the reduced demand for them is vented by a drop in their relative price. 
Finally, the response of today's trade balance to an anticipated fall in the relative price of exports can be analyzed for the case of permanent exchange controls. This response is determined by the simple differentiation the trade balance definition (4.5). This yields

$$
\frac{d t b^{1}}{d p^{* 2}}=-x_{1}^{1} \frac{d p^{* 1}\left(1+\eta^{1}\right)}{d p^{* 2}}-x_{2}^{1} \frac{d p^{* 2}\left(1+\eta^{2}\right) /\left(1+r^{*}\right)}{d p^{* 2}}+\mu_{x^{1}}^{1} \tilde{z}^{2} /\left(1+r^{*}\right)>0
$$

As can be seen, in response to an anticipated deterioration in the future terms of trade the current trade balance improves. Since the volume of imports is being controlled all of the impact on the trade balance occurs through adjustment in the export market. The last term in the above expression illustrates the beneficial impact on the trade balance that a reduction in export consumption, due the drop in welfare, has. The first and second terms show the improvement in the trade balance resulting from the decline in the current and future domestic prices of imports which lead to a contraction in current export consumption. It should be noted that without exchange controls the effect on the trade balance of an anticipated drop in the future terms of trade is ambiguous. On the one hand, the associated fall in welfare causes current import and export consumption to be cut. On the other hand, the rise in the relative price of future imports tends to stimulate current import and export consumption. The overa11 change in the trade balance would thus be ambiguous in the absence of exchange controls.

\section{Nominal Exchange Controls}

In practice nations often set the ceilings on the amount of foreign exchange that domestic residents can hold in nominal terms rather than in import equivalent units as was assumed in the previous section. This is probably because nominal targets are less costly to administer. But as will be shown this policy renders the physical volume of imports prone to both movements 
in the world general price level and to fluctuations in the terms of trade. In this section it will be assumed that the government temporarily imposes a limit in the first-period on the nominal amount of foreign exchange agents can hold. Again, let this ceiling on agents' first-period holdings of foreign currency be denoted by $\tilde{\mathrm{M}}^{* 1}$.

To begin with, consider the impact of a general increase in first-period world nominal prices (i.e. let $\mathrm{dP}^{* 1} / \mathrm{P}^{* 1}=\mathrm{dP}_{I}^{* 1} / \mathrm{P}_{I}^{* 1}$ so that $\mathrm{dp} \mathrm{p}^{* 1}=0$ ). In the first period the amount of imports, $\mathrm{z}^{1}$, that the agent can purchase is given by $\mathrm{Z}^{1}=\tilde{\mathrm{M}}^{* 1} / \mathrm{P}_{\mathrm{I}}^{* 1}\left(=\tilde{\mathrm{m}}^{* 1} / \mathrm{p}^{* 1}\right)$. Thus, a rise in the first-period nominal price of imports, $\mathrm{P}_{\mathrm{I}}^{* 1}$, represents an effective tightening of controls. Specifically, $\mathrm{dz}^{1} / \mathrm{dP}_{I}^{* 1}=$ $-\tilde{M}^{* 1} /\left(\mathrm{P}_{I}^{* 1}\right)^{2}=-\left(\mathrm{Z}^{1} / \mathrm{P}^{* 1}\right) \mathrm{dZ}^{1} / \mathrm{d} \tilde{\mathrm{m}}^{* 1}$. Therefore by recalling expressions $(4.3),(4.4)$ and $(4.6)$ it can be immediately seen that a general increase in the world price level causes a drop in domestic welfare, a rise in the first-period domestic relative price of imports, and a tendency toward a trade balance surplus. In particular,

$$
\begin{aligned}
& \mathrm{d} \underline{\mathrm{U}} / \mathrm{dP}_{\mathrm{I}}^{* 1}=-\left(\mathrm{z}^{1} / \mathrm{P}^{* 1}\right) \mathrm{d} \underline{\mathrm{U}} / \mathrm{d \tilde {m } ^ { * 1 }}<0
\end{aligned}
$$

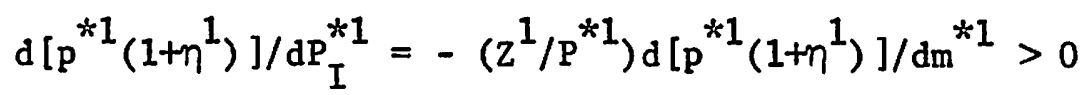

and

$$
\mathrm{dtb} / \mathrm{dP} \mathrm{I}^{* 1}=-\left(\mathrm{z}^{1} / \mathrm{P}^{* 1}\right) \mathrm{dtb} / \mathrm{dm}{ }^{* 1}>0
$$

Next, the effect of a temporary increase in the current terms of trade, $\mathrm{p}^{* 1}$, will be examined. In undertaking this exercise it will be assumed that the time path of the foreign money supply remains constant. An increase in the firstperiod terms of trade will then be associated with a rise in the current world nominal price of imports, $\mathrm{p}_{I}^{* 1}$, and a fall in the price of exports $\mathrm{P}^{* 1}$. To see this note that equilibrium in the foreign money and goods markets implies that $\sum_{j=1}^{t} T^{* j}=P^{* t}\left[\vec{X}^{* t}+p^{* t} \bar{Z}^{* t}\right]$ for all $t$, where $T^{* t}$ denotes the period-t nominal transfer 
payment that the foreign government gives to its residents, while $\bar{x}^{* t}$ and $\bar{z}^{* t}$ represent foreign residents' endowments of goods $X$ and $z$ in $t .^{11}$ It immediately follows that $\mathrm{dP}^{* \mathrm{t}} / \mathrm{dp} \mathrm{p}^{* \mathrm{t}}=-\theta^{* \mathrm{t}} \mathrm{P}^{* \mathrm{t}} / \mathrm{p}^{* \mathrm{t}}$ and $\mathrm{dP}_{\mathrm{I}}^{* \mathrm{t}} / \mathrm{dp}^{* \mathrm{t}}=\left[1-\theta^{* \mathrm{t}}\right] \mathrm{P}_{\mathrm{I}}^{* \mathrm{t}} / \mathrm{p}^{* \mathrm{t}}$ with $\theta^{* \mathrm{t}}$ being defined as the share of the import good in period-t foreign real output so that $\theta^{* t}=p^{* t} \bar{z}^{* t} /\left[\bar{x}^{* t}+p^{* t} \bar{z}^{* t}\right]$.

Now by using the above results it is easy to deduce that a temporary increase in the current terms of trade leads to a reduction in welfare of

$$
\mathrm{dU} / \mathrm{dp}{ }^{* 1}=-\mathrm{z}^{1} \mathrm{U}_{1}\left(\mathrm{x}^{1}\right)\left[1+\eta^{1}\left(1-\theta^{* 1}\right)\right]<0
$$

This drop in welfare can be broken down into two components. The first component, $\mathrm{z}^{1} \mathrm{v}_{1}\left(\mathrm{x}^{1}\right)$, represents the deterioration in welfare brought about by a "pure" increase in the terms of trade. That is, it measures the impact on welfare that an increase in the world relative price of imports has, holding the world nominal price of imports constant. As discussed, a rise in the world terms of trade, $\mathrm{p}^{* 1}$, is likely, however, to be associated with an upward movement in the world nominal price of imports, $\mathrm{P}_{I}^{* 1}$, and therefore an effective tightening of exchange controls. The price of imports represents an effective tightening of exchange controls. The second component, $z^{1} U_{1}\left(x^{1}\right) \eta^{1}\left(1-\theta^{* 1}\right)$, illustrates the welfare loss attributable to this further restriction on agents' real holdings of foreign exchange.

The impact of an increase in the current terms of trade on the first-period relative price of imports, $\mathrm{p}^{* 1}\left(1+\eta^{1}\right)$, turns out to be ambiguous. Formally,

$$
\begin{aligned}
\frac{\mathrm{d}\left[\mathrm{p}^{*}\left(1+\eta^{1}\right)\right]}{\mathrm{dp}^{* 1}}= & \frac{\left(1 /\left(1+\eta^{1}\right)\right) \mu_{\mathrm{z}^{1}}^{1}}{\mathrm{p}^{* 1} \mathrm{z}_{1}^{1}}-\frac{\left(1-\theta^{* 1}\right)\left(1-\left(\eta^{1} /\left(1+\eta^{1}\right)\right) \mu_{\mathrm{z}}^{1}\right) \mathrm{z}^{1}}{\mathrm{p}^{* 1} \mathrm{z}_{1}^{1}} \\
& \text { (reca11 that } \left.\mathrm{z}_{1}^{1}<0\right) .
\end{aligned}
$$

A "pure" increase in the world terms of trade tends to depress the domestic relative price of imports. This is because an upward movement in the 
world relative price of imports exerts a negative income effect on domestic residents and thus reduces the demand for all goods on this account. Given the fixed supply of first-period imports available to domestic residents, due to exchange controls, a drop in their price must occur so as to clear the domestic market. Thus, a pure increase in the current terms of trade is negatively transmitted to the domestic economy as discussed earlier. This is captured by the first

term of (5.2). The second term portrays the positive effect on the current domestic relative price of imports that an effective tightening of first-period exchange controls has. As can be seen, the larger (smaller) the share, $\theta^{* 1}$, of home county importables in foreign real output the more (less) dominant the terms of trade effect becomes creating a tendency for the domestic relative price of imports to fall (rise) when the current terms of trade increase. This is because the larger $\theta^{* 1}$ is the less impact a change in the world terms of trade has on the world nominal price of imports.

Finally, a tendency toward a trade balance deficit will occur when there is an upward movement in the first-period terms of trade. Specifically,

$$
\mathrm{dtb} \mathrm{b}^{1} / \mathrm{dp}{ }^{* 1}=-\left\{\mathrm{x}_{1}^{1} \mathrm{~d}\left[\mathrm{p}^{* 1}\left(1+\eta^{1}\right)\right] / \mathrm{dp}{ }^{* 1}+\mathrm{x}_{4}^{1} \mathrm{du} / \mathrm{dp}{ }^{* 1}+\theta^{* 1} \mathrm{z}^{1}\right\}<0
$$

with the negative sign of this expression being proved in the Appendix. 12

VI. Optimal Attainment of a Trade Balance Target

Governments may institute foreign exchange controls for a variety of reasons. often exchange controls are implemented during a time of economic crisis so that a target level for the current account or trade balance can be attained. It seems, however, that foreign exchange controls are likely to achieve this objective at an unnecessarily high welfare cost. To see this let $t \tilde{b}^{1}$ denote the government's target level for the trade balance in the first period. ${ }^{13}$ This target is fulfilled when 


$$
\bar{x}^{1}-x^{1}-p^{* 1} z^{1} \geq \tilde{t b}{ }^{1}
$$

Obviously, the "first-best" policy to attain this goal will be one which maximizes the agent's lifetime utility function (2.1) subject to the economy's intertemporal budget constraint (4.2) and the above trade balance target (6.1). By carrying out the prescribed maximization routine the following set of firstorder conditions--in addition the constraints (4.2) and (6.1)--emerge:

$$
\begin{aligned}
& \mathrm{U}_{1}\left(\mathrm{x}^{1}\right)=\left(1+\mathrm{r}^{*}\right)[1+(\theta / \alpha)] \rho \mathrm{U}_{1}\left(\mathrm{x}^{2}\right) \\
& \mathrm{v}_{1}\left(\mathrm{z}^{\mathrm{t}}+\overline{\mathrm{z}}^{\mathrm{t}}\right)=\mathrm{p}^{* \mathrm{t}} \mathrm{U}_{1}\left(\mathrm{x}^{\mathrm{t}}\right) \quad \mathrm{Vt}=1,2 \\
& \left(1+\mathrm{r}^{*}\right) \rho \mathrm{U}_{1}\left(\mathrm{x}^{2}\right)=\alpha
\end{aligned}
$$

where $\alpha$ and $\theta$ are the Lagrange multipliers associated with the economy's intertemporal budget constraint and trade balance target, respectively. ${ }^{14}$ In order to optimally attain the trade balance target the government must adopt a policy which generates a general equilibrium duplicating the set of conditions (4.2), $(6.1),(6.2),(6.3)$ and $(6.4) .15$

First, note that (6.3) states in each period $t$ that the marginal rate of substitution between import and export consumption, $v_{1}\left(z^{t}+\bar{z}^{t}\right) / U_{1}\left(x^{t}\right)$, should equal the world terms of trade $p^{k t}$. Thus the optimal attainment of the current account target does not imvolve driving a tariff-like wedge between the domestic and international relative prices of imports. Second, in order to efficiently attain the first-period trade balance target a wedge in the amount $(1+(\theta / \alpha))$ should be driven between one plus the domestic real rate of interest, $U_{1}\left(x^{1}\right) / \rho U_{1}\left(x^{2}\right)$, and one plus the world real rate of interest, $1+r *$ It can be seen that foreign exchange controls fail to meet both of these two efficiency criteria. Implicitly, the optimal policy involves taxing the principal and interest on borrowing from abroad at the proportionate tax rate $\epsilon$ where $\epsilon=\theta / \alpha$. Such a policy could be instituted by either implementing an explicit proportionate tax on international 
financial transactions, or by imposing quantitative restrictions on capital flows in the amount $\tilde{\mathrm{tb}}^{1}$. Also, instituting a dual exchange rate system where a separate price for foreign exchange is charged for trade balance transactions can attain this objective. ${ }^{16}$

The essential idea is that a current account target is primarily a means of achieving a given intertemporal pattern of consumption and therefore is best attained by policies that directly discriminate against consumption across periods by striking at intertemporal relative prices rather than by policies which discriminate against consumption within periods by striking at intratemporal relative prices. It is not being argued here that enforcing a target level for the trade balance is a laudable goal. In general it is not. This is easy to see since in the above problem the government is maximizing the agent's lifetime utility subject to a budget set which is artificially restricted due to the trade balance constraint (6.1). Thus in this setup the economy is at least as well off without a trade balance target as it is with one. What is being argued here, however, is that if the government desires to achieve certain policy goals relating to the various balance of payments accounts it should pick the policy best suited to directly attain this goal, a point recognized by Johnson (1965). Those advocating foreign exchange controls should precisely outline the policy objectives which such controls are aimed at accomplishing, justify why these goals are desirable, and explain why foreign exchange controls are the best available policy for attaining these ends.

VII. Conclusions

To summarize, foreign exchange controls effectively place a quota on imports. As a result they drive the domestic price of imports above the world price in exactly the same fashion as a tariff would. In many respects when foreign exchange restrictions are imposed, the imported goods market behaves in the same manner as a nontraded goods market would. It turns out that shocks to the world terms of 
trade can be negatively transmitted to the domestic economy. This occurs because the nontraded goods nature of the import market renders only the income effect from the world terms of trade shock operational. While the imposition of foreign exchanges controls can improve the trade balance and the exchange rate they reduce the welfare of a distortion-free small open economy. Finally, it is argued that foreign exchange controls are not an appropriate tool to obtain a trade balance objective. This is because the trade balance primarily reflects agents' intertemporal decision-making about how much to consume and save, while foreign exchange controls mainly impinge on individuals' intratemporal decision-making about how to allocate their within-period consumption spending between imports and exports. 


\section{Appendix}

From the representative agent's optimization problems and the various equilibrium conditions in the model it is easy to see that the following set of four equations specify the determination of $x^{1}, x^{2}, \eta^{1}\left(\right.$ or $\hat{z}^{1}$ ), and $\eta^{2}$ (or $\hat{z}^{2}$ ) in the model's general equilibrium,

$$
\begin{aligned}
& \mathrm{v}_{1}\left(\min \left(\tilde{\mathrm{z}}^{1}, \hat{\mathrm{z}}^{1}\right)+\overline{\mathrm{z}}^{-1}\right)=\mathrm{U}_{1}\left(\mathrm{x}^{1}\right) \mathrm{p}^{* 1}\left(1+\mathrm{x}_{1^{1}}\left(\tilde{\mathrm{z}}^{1}\right) \eta^{1}\right) \\
& \mathrm{v}_{2}\left(\min \left(\tilde{\mathrm{z}}^{2}, \hat{\mathrm{z}}^{2}\right)+\tilde{\mathrm{z}}^{-2}\right)=\mathrm{U}_{1}\left(\mathrm{x}^{2}\right) \mathrm{p}^{* 2}\left(1+\mathrm{x}_{\mathrm{S}^{2}}\left(\tilde{\mathrm{z}}^{2}\right) \eta^{2}\right) \\
& \mathrm{U}_{1}\left(\mathrm{x}^{1}\right)=\left(1+\mathrm{r}^{*}\right) \mathrm{OU}_{1}\left(\mathrm{x}^{2}\right) \\
& \mathrm{p}^{* 1} \min \left(\tilde{\mathrm{z}}^{1}, \hat{\mathrm{z}}^{1}\right)+\mathrm{x}^{1}+\frac{\mathrm{p}^{* 2} \min \left(\tilde{\mathrm{z}}^{2}, \hat{\mathrm{z}}^{2}\right)+\mathrm{x}^{2}}{\left(1+\mathrm{r}^{*}\right)}=\overline{\mathrm{x}}^{-1}+\frac{\overline{\mathrm{x}}^{-2}}{\left(1+\mathrm{r}^{*}\right)}
\end{aligned}
$$

where $z^{t}=\min \left(\tilde{z}^{t}, \hat{z}^{t}\right)$ and $x_{\zeta^{t}}\left(\tilde{z}^{t}\right)$ is the characteristic function associated with set $\zeta^{t}=\left\{z^{t}: z^{t} \leq \tilde{z}^{t}\right\}$, i.e., $x_{\zeta^{t}}=1$ if $z^{t}=\tilde{z}^{t}$ and $x_{\zeta^{t}}=0$ if $z^{t}<\tilde{z}^{t}$.

For the case of temporary first-period exchange controls, discussed in the text, the endogenous variables in the above system of equations will be $x^{1}, x^{2}, \eta^{1}$ and $\hat{z}^{2}$. By performing the specified comparative static exercise it is easy to see that

$$
\frac{d x^{2}}{d \tilde{m}^{* 1}}=-\frac{U_{1}\left(x^{1}\right) p^{* 1} U_{11}\left(x^{1}\right) p^{* 2} U_{11}\left(x^{2}\right) p^{* 1}}{\Pi}<0
$$

and

$$
\frac{\mathrm{d} \hat{\mathrm{z}}^{2}}{\mathrm{~d} \tilde{\mathrm{m}}^{* 1}}=-\frac{\mathrm{U}_{1}\left(\mathrm{x}^{1}\right) \mathrm{p}^{* 1} \mathrm{v}_{11}\left(\hat{\mathrm{z}}^{2}+\overline{\mathrm{Z}}^{2}\right) \mathrm{U}_{11}\left(\mathrm{x}^{1}\right) \mathrm{p}^{* 1}}{\Pi}<0
$$

so that

$$
\frac{d t b^{1}}{d \tilde{m}^{* 1}}=\frac{1}{1+r^{*}}\left[\frac{d x^{2}}{d \tilde{m}^{* 1}}+p^{* 2} \frac{d \hat{z}^{2}}{d \tilde{m}^{* 1}}\right]<0 \quad \text { (c.f. ftn. 8) }
$$

with

$$
\begin{array}{r}
\Pi \equiv u\left(x^{1}\right) p^{* 1}\left\{v_{11}\left(\hat{z}^{2}+\bar{z}^{2}\right)\left[U_{11}\left(x^{1}\right) /\left(1+r^{*}\right)+\rho(1+r *) U_{11}\left(x^{2}\right)\right]+U_{11}\left(x^{2}\right) p^{* 2} U_{11}\left(x^{1}\right)\right. \\
\left.\cdot p^{* 2} /\left(1+r^{*}\right)\right\}>0
\end{array}
$$


Finally, consider the situation where first-period nominal exchange controls are temporarily in effect. Here the endogenous variables are $x^{1}, \eta^{1}$, $x^{2}$ and $\hat{z}^{2}$. It is easy to show that $x^{2}$, and $\hat{z}^{2}$ respond in the following fashion to a temporary shift in the first-period terms of trade, $p^{* 1}$

$$
\begin{gathered}
\frac{d x^{2}}{d p^{* 1}}=-\frac{\theta^{* 1} \tilde{z}_{1}^{1} U_{1}\left(x^{1}\right) p^{* 1} v_{11}\left(\hat{z}^{2}+\bar{z}^{2}\right) U_{11}\left(x^{1}\right)}{\pi}<0 \\
\frac{d \hat{z}^{2}}{d p^{* 1}}=-\frac{\theta^{* 1} \tilde{z}^{1} U_{1}\left(x^{1}\right) p^{* 1} U_{11}\left(x^{2}\right) p^{* 2} U_{11}\left(x^{1}\right)}{\pi}<0 \\
\left(0<\theta^{* 1}<1\right)
\end{gathered}
$$

so that $d t b^{1} / d p^{* 1}<0$ as was shown by equation $(5.3)$ in the text. 


\section{Footnotes}

${ }^{1}$ It will be assumed that $\underline{U}(\cdot)$ is a strictly quasi-concave class $c^{2}$ function. The term $\bar{Z}^{-t}$ in $V(\cdot)$ is a constant and merely serves to simplify the analysis. This will be readily apparent later on.

${ }^{2}$ Cash-in-advance models similar in style to the one utilized here have also been employed by Stockman (1980), Lucas (1982), and Persson (1984).

3

This notation can be translated into the above two period environment by utilizing the following definitions: $\mathrm{r}^{* 1} \equiv \mathrm{r}^{*} ; \mathrm{r}^{* 2} \equiv 0, \pi^{1} \equiv\left(\mathrm{P}^{2}-\mathrm{P}^{1}\right) / \mathrm{P}^{1}, \pi^{2} \equiv \infty$, $\pi^{* 1} \equiv\left(\mathrm{P}^{* 2}-\mathrm{P}^{* 1}\right) / \mathrm{P}^{* 1}$, and $\pi^{* 2} \equiv \infty$.

${ }^{4}$ For instance, consider the agent's decision regarding his first period holdings of cash balances. His first-order conditions regarding how many bonds and how much domestic money to hold in the first period are: $\alpha^{1}=\left(1+r^{*}\right) \alpha^{2}$ and $\alpha^{1}=\left[1 /\left(1+\pi^{1}\right)\right] \alpha^{2}+\beta^{1}$, where $\alpha^{1}$ is the Lagrange multipliex associated with the budget constraint $(3.1)$ and $\beta^{1}$ is the multiplier linked with the first cash-in-advance constraint in (3.3). Thus $\beta^{1}=\left[\left(\pi^{1}+x *^{1}+\pi^{1} r *^{1}\right) /\left(1+\pi^{1}\right)\left(1+x^{*^{1}}\right)\right] \alpha^{1}$. Hence if $\pi^{1}>-r *^{1} /\left(1+r *^{1}\right)$ then $\beta^{1}>0$. 5 Formally, the Kuhn-Tucker conditions associated with the foreign exchange restrictions are: $\tilde{\mathfrak{m}}^{* t}-\mathrm{m}^{* t} \geq 0, \lambda^{t} \geq 0$ and $\lambda^{t}\left(\tilde{\mathfrak{m}}^{* t}-\mathrm{m}^{* t}\right)=0, \forall t=1,2$. Thus whenever the multiplier, $\lambda^{t}$, is greater than zero the period-t exchange controls are binding. The converse, however, is not generally true. For simplicity, it will be assumed that if the foreign exchange constraint is binding then the multiplier, $\lambda$, is strictly positive in value.

${ }^{6}$ That controls on international transactions can be analyzed from the perspective of a competitive market generating an (implicit) market-clearing price for the controlled quantity has been discussed, for the case of capital controls, by Obstfeld (1984) and Adams and Greenwood (1984). 
${ }^{7}$ Since the cash-in-advance constraints (3.3) and (3.4) hold as strict equalities, $x^{t}+\left(1+\eta^{t}\right) p^{* t} z^{t}=m^{t}$. Similar conditions will hold in the rest of the world so that if $x_{F}^{t}$ is defined as the "foreign" country's purchases of domestic output and $M_{F}^{t}$ as its holdings of domestic real cash balances then $x_{F}^{t}=m_{F}^{t}$. Equilibrium in the domestic goods and money markets in period $t$ requires that $x^{t}+x_{F}^{t}=\bar{x}^{t}$ and $m^{t}+m_{F}^{t}=\Sigma_{j=1}^{t} T^{j} / P^{t}$. Thus, $\bar{x}^{t}+\left(1+\eta^{t}\right) p^{* t} \bar{z}^{t}=\Sigma_{j=1}^{t} T^{j} / P^{t}$ where the lefthand side of this expression represents the demand for domestic real cash balances and the right-hand side the supply.

${ }^{8}$ Expression $(4.6)$ can also be presented in alternative manner. From (4.2) and (4.5) note that the trade balance can be equivalently written as $t b^{1}=-(1 /(1+r *))\left[\bar{x}^{2}-x^{2}-p^{* 2} z^{2}\right]$. Differentiating this expression yields $\frac{d t b^{1}}{d \tilde{m}^{* 1}}=\frac{1}{\left(1+r^{*}\right)}\left\{\left[\left(1+r^{*}\right) \eta^{1}\left(\mu_{x}^{2}+\mu_{z}^{2}\right)\right]+\left[\left(x_{1}^{2}+p^{* 2} z_{1}^{2}\right) \frac{d p^{* 1}\left(1+\eta^{1}\right)}{d \tilde{m}^{* 1}}\right]\right\}<0$ As discussed, when the foreign exchange controls are relaxed the agent realizes an improvement in welfare. To the extent that he uses this welfare gain to increase his future consumption the current trade balance improves, as the first term in brackets illustrates. The liberalization of first-period exchange controls tends to reduce the current domestic relative price of imports. This causes a substitution away from future consumption toward the consumption of first-period imports which worsens today's trade balance. This effect is captured by the second term in brackets in the above expression.

${ }^{9}$ The current model can easily be adapted to analyze the balance of payments under a fixed exchange rate system. In the present setup the choice of exchange rate regime is irrelevant for the economy's real equilibrium as long as under a fixed exchange rate system the monetary authority uses interest-bearing reserves in 
any exchange rate stabilization schemes it pursues--see Helpman (1981) and Persson (1984). It is easy to deduce from the line of argument just presented in the text that under a fixed exchange rate system a liberalization of exchange controls will lead to a deterioration in the balance of payments. Often devaluations occur in the presence of exchange controls. Unlike Aizenman (1981), a devaluation in the current model would have no real effects, with or without exchange controls in place--assume that the devaluation takes place at the beginning of the first-period. This obtains for two reasons: (i) there are no wealth effects from money in the model's general equilibrium and (ii) the monetary authority's holdings of interest-bearing reserves would be irrelevant for consumption allocations in the model. By contrast, a devaluation in the present model with capital controls in place would have real effects because private capital flows will no longer offset changes in the monetary authority's holdings of interest-bearing reserves--see Obstfeld (1984).

$$
\begin{aligned}
& { }^{10} \text { Just to be clear, } \mathrm{z}_{2}^{2} \equiv \partial \mathrm{z}^{2} / \partial\left[\mathrm{p}^{* 2}\left(1+\eta^{2}\right) /(1+\mathrm{r} *)\right]<0 \text {, } \\
& \mathrm{z}_{2}^{1} \equiv \partial \mathrm{z}^{1} / \partial\left[\mathrm{p}^{* 2}\left(1+\eta^{2}\right) /\left(1+\mathrm{r}^{*}\right)\right]>0, \quad \mathrm{z}_{1}^{2}=\partial \mathrm{z}^{2} / \partial\left[\mathrm{p}^{* 1}\left(1+\eta^{1}\right)\right]>0, \text { and } \mathrm{z}_{4}^{2} \equiv \partial \mathrm{z}^{2} / \partial \mathrm{U}>0 \text {. }
\end{aligned}
$$

${ }^{11}$ See footnote 7

${ }^{12}$ To aid in understanding this expression consider two cases. First, let $\theta^{* 1}=1$ so that a pure change in the terms of trade is being examined. Here the domestic price of first-period imports falls (c.f. (5.1)) and tends to reduce current export consumption and improve the trade balance, as the first term shows. The second term illustrates the reduction in export consumption caused by the fall in welfare which also tends to improve the trade balance. The third term portrays the increase in the real value of imports, $\mathrm{p}^{* 1} \mathrm{z}^{1}$, brought about by the rise in the terms of trade and operates to worsen the trade balance. The first and second terms are dominated by the third. Next consider the case where $\theta^{* 1}=0$. The third term disappear 
here since $\mathrm{p}^{* 1} \mathrm{z}^{1}$ remains constant; the increase in $\mathrm{p}^{* 1}$ is exactly offset by the fall in $\mathrm{z}^{1}$ caused by the rise in $\mathrm{P}_{I}^{* 1}$. Now the domestic relative price of imports rises (c.f. (5.1)) and this stimulates export consumption and worsens the trade balance, as shown by the first term. The second term operates in the same manner as before and thus works to improve the trade balance. Here the first and second terms have exactly offset one another and $\mathrm{dtb}^{1} / \mathrm{dp}^{* 1}=0$. If $0<\theta^{* 1}<1$ the change in the trade balance will be a weighted average of these two cases and hence $d t b^{1} / \mathrm{dp}^{* 1}<0$.

${ }^{13}$ One might first ask whether it is feasible to use first-period exchange controls to attain the target level for the trade balance, $\tilde{t b}^{1}$. The answer is yes. To see this note that $(3.8),(4.2)$, and (4.5) imply a unique solution $x^{2}$ which is given by the equation $\left.v_{1}\left(\bar{x}^{2}+p^{* 2} \bar{z}^{2}+\left(1+r^{*}\right) t \tilde{b}^{1}-x^{2}\right) / p^{* 2}\right)=p^{* 2} U_{1}\left(x^{2}\right)$. This solution for $x^{2}$ when used in conjunction with (3.9) provides a unique value for $\mathrm{x}^{1}$. Finally, a unique for $\mathrm{z}^{1}\left(=\tilde{\mathrm{m}}^{* 1} / \mathrm{p}^{* 1}\right)$ is then obtained from (6.1).

${ }^{14}$ Formally, the government's optimization problem is

$$
\begin{aligned}
\operatorname{Max} & \left\{U\left(x^{1}\right)+v\left(z^{1}+\bar{z}^{1}\right)+\rho\left[U\left(x^{2}\right)+v\left(z^{2}+\bar{z}^{2}\right)\right]\right\} \\
& +\alpha\left[\bar{x}^{-1}-x^{1}-p^{* 1} z^{1}+\left(1 /\left(1+x^{*}\right)\right)\left(\bar{x}^{2}-x^{2}-p^{* 2} z^{2}\right)\right]+\theta\left[\bar{x}^{1}-x^{1}-p^{* 1} z-\tilde{t} b^{1}\right]
\end{aligned}
$$

with the choice variables being $x^{1}, z^{1}, x^{2}$ and $z^{2}$. The variable $\alpha$ represents the marginal utility of wealth, while $\theta$ illustrates the welfare loss--measured in utility terms--associated with a marginal increase in the trade balance target. It will be assumed that the trade balance constraint (6.1) is binding.

${ }^{15}$ Since $\underline{U}(\cdot)$ is strictly quasi-concave while the constraints $(4.2),(6.1)$ are convex the first-order conditions $(4.2),(6.1),(6.2),(6.3)$ and $(6.4)$ are both necessary and sufficient for a maximum. Also, the implied solution generated for $x^{1}, z^{1}, x^{2}$ and $z^{2}$ is unique. Again, as mentioned in footnote 14 , it will be assumed that (6.1) is binding. 
${ }^{16}$ In more general settings than the one adopted here such policies can have an additional channel of impact on the economy via their impact on the nominal interest rate. In the simple model adopted here the real and monetary sides of the economy are separate and consequently this avenue of effect is not operational. For an example where it is, see Adams and Greenwood (1984). To see the equivalence of a trade balance target and capital controls in the model, note that under a flexible exchange rate system the trade balance (actually the current account) is equal to the negative of the capital account. Controlling one is therefore equivalent to controlling the other. 


\section{References}

Adams, Charles and Greenwood, Jeremy, "Dual Exchange Rate Systems and Capital Controls," Working Paper No. 8427C, London, Ontario: Centre for the Study of International Economic Relations, University of Western Ontario, June 1984, forthcoming Journal of International Economics.

Aizenman, Joshua, "Devaluation and Liberalization in the Presence of a Tariff and Quota Restrictions: An Equilibrium Mode1," Journal of Internationa1 Economics, Vo1. 11, No. 2: 197-206, May 1981.

Bhagwati, Jagdish N. "On the Equivalence of Tariffs and Quotas," in Trade, Growth, and the Balance of Payments, edited by Robert E. Baldwin et a1. Chicago: Rand McNalley and Co., 1965: 53-67.

Greenwood, Jeremy, "Nontraded Goods, the Trade Balance, and the Balance of Payments," Working Paper No. 8417C, London, Ontario: Centre for the Study of International Economic Relations, University of Western Ontario, November 1983, forthcoming, Canadian Journal of Economics.

Helpman, Elhanan, "An Exploration in the Theory of Exchange Rate Regimes," Journal of Political Economy, Vol. 89, No. 5: 865-890, October 1981. Johnson, Harry G., "Optimal Trade Intervention in the Presence of Domestic Distortions," in Trade, Growth and the Balance of Payments, edited by Robert E. Baldwin et al. Chicago: Rand McNalley and Co., 1965: 3-34.

Jones, Ronald W., "Trade with Nontraded Goods: the Anatomy of Interconnected Markets," Economica, Vol. 41: 121-138, May 1974.

Kimbrough, Kent P., "An Examination of the Effects of Government Purchases in an Open Economy," unpublished manuscript. Durham, N.C.: Duke University, November 1983, Forthcoming, Journal of International Money and Finance. 
Lucas, Robert E., "Interest Rates and Currency Prices in a Two-Country World," Journal of Monetary Economics, Vol. 10, No. 3: 335-360, November 1982.

Obstfeld, Maurice, "Capital Controls, The Dual Exchange Rate, and Devaluation," Working Paper No. 8423C, London, Ontario: Centre for the Study of International Economic Relations, University of Western Ontario, January 1984.

Persson, Torsten, "Real Transfers in Fixed Exchange Rate Systems and the International Adjustment Mechanism," Journal of Monetary Economics, Vo1. 13, No. 3: 349-369, May 1984 .

Stockman, Alan C., "A Theory of Exchange Rate Determination," Journal of Political Economy, Vo1. 88, No. 4: 673-698, August 1980. 


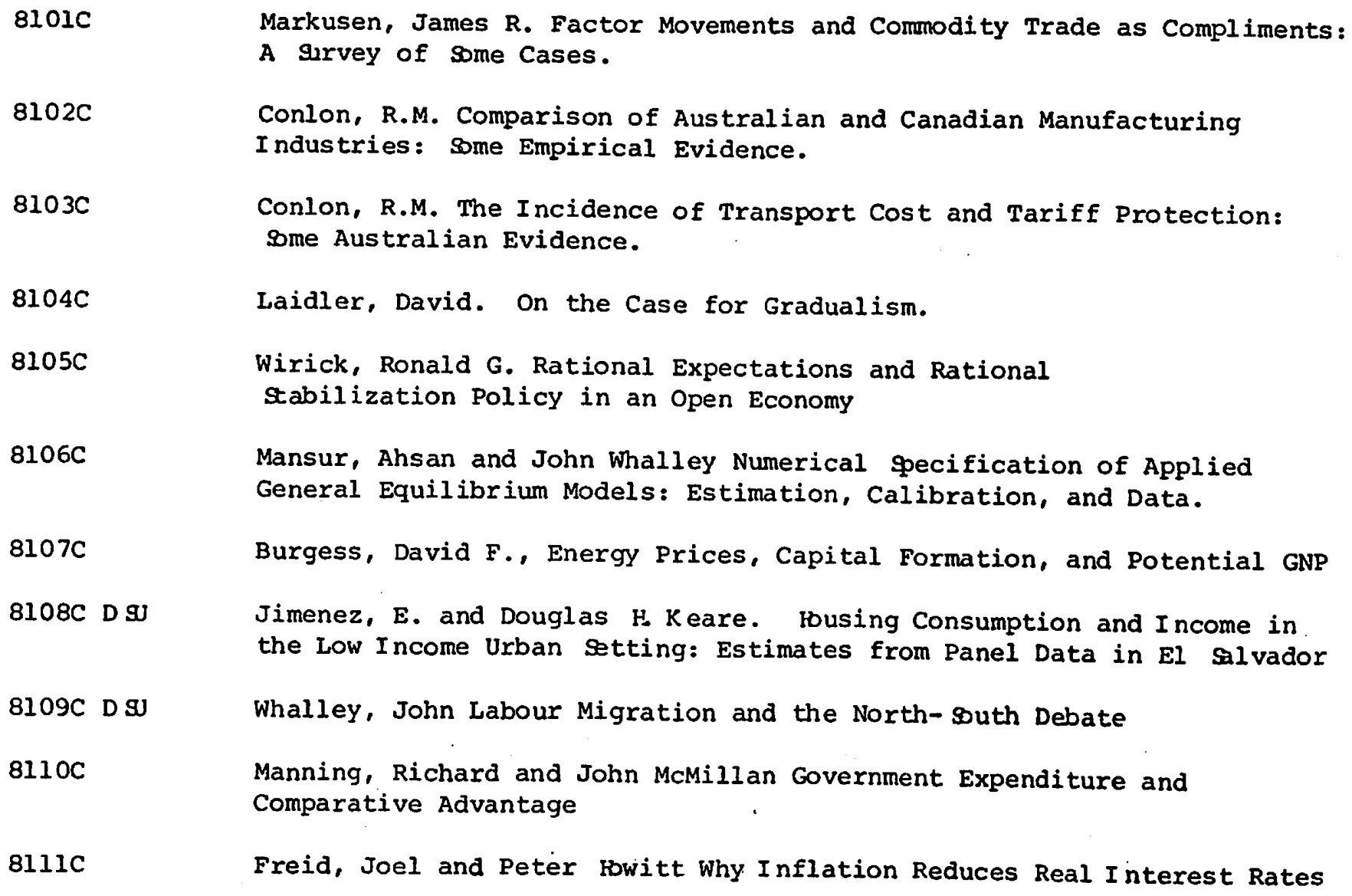

Markusen, James R. Factor Movements and Commodity Trade as Compliments: A Survey of Some Cases.

Conlon, R.M. Comparison of Australian and Canadian Manufacturing Industries: Some Empirical Evidence.

Conlon, R.M. The Incidence of Transport cost and Tariff Protection: Some Australian Evidence.

Laidler, David. On the Case for Gradualism.

Wirick, Ronald G. Rational Expectations and Rational Stabilization Policy in an Open Economy

Mansur, Ahsan and John Whalley Numerical Secification of Applied General Equilibrium Models: Estimation, Calibration, and Data. Burgess, David F., Energy Prices, Capital Formation, and Potential GNP Jimenez, E. and Douglas $\mathrm{H}$ Keare. Housing Consumption and Income in the Low Income Urban Setting: Estimates from Panel Data in El Salvador Whalley, John Labour Migration and the North-South Debate Manning, Richard and John McMillan Government Expenditure and Comparative Advantage

Freid, Joel and Peter bowitt Why Inflation Reduces Real I nterest Rates

\section{2}

Manning, Richard and James R. Markusen Dynamic Non-Substitution and Long Run Production Possibilities

Feenstra, Robert and Ken Judd Tariffs, Technology Transfer, and Welfare

Ronald W. Jones, and Douglas D. Purvis: International Differences in Response to Common External Shocks: The Role of Purchasing Power Parity

James A Brander and Barbara J. Spencer: Industrial strategy with Committed Firms

Whalley, John, The North-South Debate and the Terms of Trade: An Applied General Equilibrium Approach

Roger Betancourt, Christopher Clague, Arvind Panagariya CAPI TAL UTI IIZATI ON IN GENERAL EDUILT BRT UM

Mansur, Ahsan $H_{4}$ On the Estimation of Import and Export Demand Elasticities and Elasticity Pessimism.

Whalley, J. and Randy Wigle PRICE AND QUANTITY RIGIDITIES IN ADJUSTMENT TO TRADE POLICY CHANGES: ALTERNATIVE FORMULATIONS AND INITIAL CALCULATIONS

Jimenez, E. SQUATTING AND COMMUNITY ORGANIZATION IN DEVELOPING COUNTRIES:
A CONCEPTUAL FRAMEWORK 
8210C Grossman, G.M. INTERNATIONAL COMPETITION AND THE UNIONIZED SECTOR

8211C Laidler,D. FRIEDMAN AND SCHWARTZ ON MONETARY TRENDS - A REVIEW ARTICLE

8212C Imam, M.H. and Whalley, J. INCIDENCE ANALYSIS OF A SECTOR SPECIFIC MINIMUM WAGE IN A TWO SECTOR HARRIS-TODARO MODEL.

8213C Markusen, J.R. and Melvin, J.R. THE GAINS FROM TRADE THEOREM WITH INCREASING
RETURNS TO SCALE.

8214C INDUSTRIAL ORGANIZATION AND THE GENERAL EQUILIBRIUM COSTS OF PROTECTION IN
SMALL OPEN ECONOMIES.

8215C Laidler, D. DID MACROECONOMICS NEED THE RATIONAL EXPECTATIONS REVOLUTION?

8216C Whalley, J. and Wigle, R. ARE DEVELOPED COUNTRY MULTILATERAL TARIFF REDUCTIONS NECESSARILY BENEFICIAL FOR THE U.S.?

8217C Bade, $R$. and Parkin, $M$. IS STERLING M3 THE RIGHT AGGREGATE?

8218C Kosch, B. FIXED PRICE EQUIIIBRIA IN OPEN ECONOMIES.

\section{$\underline{1983}$}

8301C Kimbell, L.J. and Harrison, G.W. ON THE SOLUTION OF GENERAL EQUILIBRIUM
MODELS.

8302C Melvin, J.R. A GENERAL EQUILIBRIUM ANALYSIS OF'CANADIAN OIL POLICY.

8303C Markusen, J.R. and Svensson, L.E.0. TRADE IN GOODS AND FACTORS WITH
INTERNATIONAL DIFFERENCES IN TECHNOLOGY

8304C Mohammad, S. Whalley, J. RENT SEEKING IN INDIA: ITS COSTS AND POLICY
SIGNIFICANCE.

8305C DSU Jimenez, E. TENURE SECURITY AND URBAN SQUUATING.

8306C Parkin, M. WHAT CAN MACROECONOMIC THEORY TELL US ABOUT THE WAY DEFICITS
SHOULD BE MEASURED.

830?C Parkin, M. THE INFLATION DEBATE: AN ATTEMPT TO CLEAR THE AIR.

8308C Wooton, I. LABOUR MIGRATION IN A MODEL OF NORTH-SOUTH TRADE.

$\begin{array}{ll}8309 \mathrm{C} & \text { Deardorff, A.V. THE DIRECTIONS OF DEVELOPING COUNTRIES TRADE: EXAMPLES } \\ \text { FROM PURE THEORY. }\end{array}$ 8310C Manning, R. ADVANTAGEOUS REALLOCATIONS AND MULTIPLE EQUILIBRIA: RESULTS
FOR THE THREE-AGENT TRANSFER PROBLEM. 

8311C DSU Mohamnad, S. and Whalley, J. CONTROLS AND THE INTERSECTORAL TERMS OF
TRADE IN INDIA.

8312C Brecher, Richard A. and Choudhri, Ehsan U. NEW PRODUCTS AND THE FACTOR CONTENT OF INTERNATIONAL TRADE.

$8313 \mathrm{C}$ Jones, R.W., Neary, J.P. and Ruane, F.P. TWO-WAY CAPITAL FLOWS: CROSSHAULING IN A MODEL OF FOREIGN INVESTMENT.

8314C DSU Follain, J.R. Jr, and Jimenez, E. THE DEMAND FOR HOUSING CHARACTERISTICS IN DEVELOPING COUNTRIES.

8315C Shoven, J.B. and Whalley, J. APPLIED GENERAL EQUILIBRIUM MODELS OF TAXATION AND INTERNATIONAL TRADE.

8316C Boothe, Paul and Longworth David. SOME IRREGULAR REGULARITIES IN THE CANADIAN/U.S. EXCHANGE MARKET.

8317C Hamilton, Bob and Whalley, John. BORDER TAX ADJUSTMENTS AND U.S. TRADE.

8318C Neary, J. Peter, and Schweinberger, Albert G. FACTOR CONTENT FUNCTIONS AND THE THEORY OF INTERNATIONAL TRADE.

8319C Veall, Michael R. THE EXPENDITURE TAX AND PROGRESSIVITY.

8320C Melvin, James R. DOMESTIC EXCHANGE, TRANSPORTATION COSTS AND INTERNATIONAL TRADE.

8321C Hamilton, Bob and Whalley, John. GEOGRAPHICALLY DISCRIMINATORY TRADE ARRANGEMENTS .

8322C Bale, Harvey Jr. INVESTMENT FRICTIONS AND OPPORTUNITIES IN BILATERAL U.S.-CANADIAN TRADE RELATIONS.

8323C Wonnacott, R.J. CANADA-U.S. ECONOMIC RELATIONS-A CANADIAN VIEW.

8324C Stern, Robert M. U.S.-CANADIAN TRADE AND INVESTMENT FRICTIONS: THE

8325C Harrison, Glenn, H. and Kimbe11, Larry, J. HOW ROBUST IS NUMERICAL GENERAL EQUILIBRIUM ANALYSIS?

8326C Wonnacott, R.J. THE TASK FORCE PROPOSAL ON AUTO CONTENT: WOULD THIS SIMPLY EXTEND THE AUTO PACT, OR PUT IT AT SERIOUS RISK?

8327C Bradford, James C. CANADIAN DEFENCE TRADE WITH THE U.S. Conklin, David. SUBSIDY PACTS .

Rugman, Alan M. THE BEHAVIOUR OF U.S. SUBSIDARIES IN CANADA:

IMPLICATIONS FOR TRADE AND INVESTMENTS. 
8328C Boyer, Kenneth D. U.S.-CANADIAN TRANSPORTATION ISSUES.

8329C Bird, Richard M. and Brean, Donald J.S. CANADA-U.S. TAX RELATIONS: ISSUES AND PERSPECTIVES.

8330C Moroz, Andrew R. CANADA-UNITED STATES AUTOMOTIVE TRADE AND TRADE POLICY ISSUES.

8331C Grey, Rodney de C. and Curtis, John. INSTITUTIONAL ARRANGEMENTS FOR U.S.-CANADIAN NEGOTIATIONS. PART I: CANADA-U.S. TRADE AND ECONOMIC ISSUES: DO WE NEED A NEW INSTITUTION? PART II: INSTITUTIONAL ARRANGEMENTS FOR MANAGING THE CANADA-U.S. ECONOMIC RELATIONSHIP.

$\underline{1984}$

8401C Harrison, Glenn $\mathrm{W}$. and Manning, Richard. BEST APPROXIMATE AGGREGATION OF INPUT-OUTPUT SYSTEMS.

8402C Parkin, Michael. CORE INIFLATION: A REVIEW ESSAY.

8403C Blomqvist, Ȧke, and McMahon, Gary. SIMULATING COMMERICAL POLICY IN A SMALL, OPEN DUAL ECONOMY WITH URBAN UNEMPLOYMENT: A GENERAL EQUILIBRIUM APPROACH.

8404C Wonnacott, Ronald. THE THEORY OF TRADE DISCRIMINATION: THE MIRROR IMAGE OF VINERIAN PREFERENCE THEORY?

8405C Whalley, John. IMPACTS OF A 50\% TARIFF REDUCTION IN AN EIGHT-REGION GLOBAL TRADE MODEL.

8406C Harrison, Glenn W. A GENERAL EQUILIBRIUM ANALYSIS OF TARIFT REDUCTIONS.

8407C Horstmann, Ignatius and Markusen, James R. STRATEGIC INVESTMENTS AND THE DEVELOPMENT OF MULTINATIONALS.

8408C Gregory, Allan W. and McCurdy, Thomas H. TESTING THE UNBIASEDNESS HYPOTHESIS IN THE FORWARD FOREIGN EXCHANGE MARKET: A SPECIFICATION ANALYSIS.

8409C Jones, Ronald W. and Kierzkowski, Henryk. NEIGHBORHOOD PRODUCTION STRUCTURES WITH APPLICATIONS TO THE THEORY OF INTERNATIONAL TRADE.

$8410 \mathrm{C}$ Weller, Paul and Yano, Makoto. THE ROLE OF FUTURES MARKETS IN INTERNATIONAL TRADE: A GENERAL EỌUILIBRIUM APPROACH.

8411C Brecher, Richard A. and Bhagwati, Jagdish N. VOLUNTARY EXPORT RESTRICTIONS VERSUS IMPORT RESTRICTIONS: A WELFARE-THEORETIC COMPARISON. 
8412C Ethier, Wilfred J. ILLEGAL IMMIGRATION.

8413C Eaton, Jonathon and Gene M. Grossman. OPTIMAL TRADE AND INDUSTRIAL POLICY UNDER OLIGOPOLY.

$8414 \mathrm{C}$ Wooton, Ian. PREFERENTIAL TRADING AGREEMENTS - A 3xn MODEL.

8415C Parkin, Michael. DISCRIMINATIN, BETWEEN KEYNESIAN AND CLASSICAL THEORIES OF THE BUSINESS CYCLE: JAPAN 1967-1982

8416C Deardorff, Alan V. FIRless FIRwoes: HOW PREFERENCES CAN INTERFERE WITH THE THEOREMS OF INTERNATIONAL TRADE.

8417C Greenwood, Jeremy. NONTRADED GOODS, THE TRADE BALANCE, AND THE BALANCE OF PAYMENTS.

8418C Blomqvist, Ake and Sharif Mohammad. CONTROLS, CORRUPTION, AND COMPETITIVE RENT-SEEKING IN LDCs.

8419C Grossman, Herschel I. POLICY, RATIONAL EXPECTATIONS, AND POSITIVE ECONOMIC ANALYSIS.

8420C Garber, Peter M. and Robert G. King. DEEP STRUCTURAL EXCAVATION? A CRITIOUE OF EULER EQUATION METHODS.

8421C Barro, Robert J. THE BEHAVIOR OF U.S. DEFICITS.

8422C Persson, Torsten and Lars E.0. Svensson. INTERNATIONAL BORROWING AND TIME-CONSISTENT FISCAL POLICY.

8423C Obstfeld Maurice. CAPITAL CONTROLS, THE DUAL EXCHANGE RATE, AND DEVALUATION.

8424C Kuhn, Peter. UNION PRODUCTIVITY EFFECTS AND ECONOMIC EFFICIENCY.

8425C Hamilton, Bob and John Whalley. TAX TREATMENT OF HOUSING IN A DYNAMIC SEỌUENCED GENERAL EOUUILIBRIUM MODEL.

8426C Hamilton, Bob, Sharif Mohammad, and John Whalley. RENT SEEKING AND THE NORTH-SOUTH TERMS OF TRADE.

8427C Adams, Charles and Jeremy Greenwood. DUAL EXCHANGE RATE SYSTEMS AND CAPITAL CONTROLS: AN INVESTIGATION.

8428 Loh, Choon Cheong and Michael $\mathrm{R}$. Veall. A NOTE ON SOCIAL SECURITY AND PRIVATE SAVINGS IN SINGAPORE.

8429 Whalley, John. RFGRESSION OR PROGRESSION: THE TAYING OUESTION OF INCIDENCE ANALYSIS.

8430 Kuhn, Peter. WAGES, EFFORT, AND INCENTIVE-COMPATIBILITY IN LIFE-CYCLE EMPLOYMENT CONTRACTS. 
8431 Greenwood, Jeremy and Kent P. Kimbrough. AN INVESTIGATION IN THE THEORY OF FOREIGN EXCHANGE CONTROLS.

8432 Greenwood, Jeremy and Kent P. Kimbrough. CAPITAL CONTROLS AND THE INTERNATIONAL TRANSMISSION OF FISCAL POLICY.

8433 : Nguyen, Trien Trien and John Whalley. EOUILIBRIUM UNDER PRICE CONTROLS WITH ENDOGENOUS TRANSACTIONS COSTS.

8434 Adams, Charles and Russell S. Boyer. EFFICIENCY AND A SIMPLE MODEL OF EXCHANGE RATE DETERMINATION.

8435 Kuhn, Peter. UNIONS, ENTREPRENEURSHIP, AND EFFICIENCY. 